\title{
PENGARUH KEPEMIMPINAN KEPALA MADRASAH TERHADAP KINERJA GURU PADA MAS SE-KABUPATEN TANAH DATAR
}

\author{
Ikhwandra \\ Pengawas di Lingkungan Kemenag tanah Datar \\ Koresponden: Nan IX Kenarian Salimpaung Kabupaten Tanah Datar, \\ e-mail: ikhwandra@yahoo.com

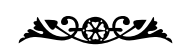

\begin{abstract}
Abstrak; Effect of Leadership Head Madrasah on The Performance Teacher In MAS se-Kabupaten Tanah Datar. The purpose of this research was to reveal how extend the correlations of of the school principal's leadership and the teamwork towarthe teachers' performance of Privat Islamic Senior High at Tanah Datar Regency.There were three hypotheses to be tested : the school principal's leadership contributed significantly toward the teachers' performance; of Privat Islamic Senior High at Tanah Datar Regency.

Research population were all teacher of privat Islamic Senior High at Tanah Datar Regency of 386 teachers from which 59 teachers were selected as a research sample by means of the stratified proportional random sampling technique. The result of data analyses show that a) the school principal's leadership contributed significantly $(24,1 \%)$ toward the teachers' performance;
\end{abstract}

Kata kunci: Kepemimpinan, kepala madrasah, kinerja guru

\section{PENDAHULUAN}

Kinerja guru dipengaruhi oleh beberapa faktor antara lain intelegensi, sikap, kemampuan professional, ketrampilan menajemen, keamanan, suasana atau kerja tim, perencanaan, kepemimpinan dan pengawasan. Faktor-faktor tersebut sebagaimana dikemukakan oleh Siagian (2002) bahwa ada beberapa faktor yang dapat mempengaruhi kinerja antara lain : (1) Intelegensi, (2) Sikap, (3) Kemampuan professional guru, (4) Ketrampilan menajemen, (5) Suasana atau iklim kerja sama (kerja tim), (6) Keamanan dan perlindungan kerja, (7) Perencanaan, (8) Pengawasan, (9) Motivasi internal, (10) kepemimpinan kepala sekolah.

Di sebuah madrasah yang berfungsi sebagai pemimpin adalah kepala madrasah itu sendiri. Seorang kepala madrasah yang memimpin sebuah lembaga pendidikan bertugas memenuhi kebutuhan kelompok yang dipimpinnya, yakni lembaga 
pendidikan. Menurut M. Ngalim Purwanto (2004) bahwa:

Tugas seorang pemimpin lembaga pendidikan, kecuali harus memenuhi kebutuhan kelompok juga harus dapat mempengaruhi kelompok sedemikian rupa sehingga apa yang dirasakan sebagai kebutuhan benar-benar bersifat realistis, yaitu sesuai dengan kenyataan, idam-idam mau kelompok yang buruk-buruk atau hanya khayalan belaka harus dirombak oleh pemimpin ke dalam kehendak yang realistis

Data tahun terakhir tentang hasil belajar siswa dalam mengikuti UN di tingkat Madarasah Aliyah Swasta di Kabupaten Tanah Datar tahun pelajaran 2011/2012 adalah:

Tabel 1

Porsentase Tingkat Lulusan Madarasah Aliyah Swasta (MAS Se-Kabupaten Tanah Datar

\begin{tabular}{|c|c|c|c|c|c|c|}
\hline \multirow{2}{*}{ No } & \multirow{2}{*}{ Jurusan } & \multirow{2}{*}{$\begin{array}{l}\text { Tingkat } \\
\text { lulus }\end{array}$} & \multirow{2}{*}{\begin{tabular}{|l} 
Tidak \\
lulus
\end{tabular}} & \multicolumn{3}{|c|}{ Tidak lulus } \\
\hline & & & & $\mathrm{Jml}$ & Swasta & Negeri \\
\hline 1 & Agama & $96,55 \%$ & $3.45 \%$ & 13 orang & 12 orang $(92 \%)$ & 1 orang $(8 \%)$ \\
\hline 2 & IPS & 97,67 & $2,33 \%$ & 3 orang & 3 orang $(100 \%)$ & - \\
\hline
\end{tabular}

Sumber Data: dari Mapenda Kementerian Agama Kabupaten Tanah Datar

Dari data ini dapat disimpulkan bahwa pada Madarasah Aliyah Swasta (MAS) sekabupaten Tanah Datar tingkat ketidak lulusan sangatlah tinggi dibandingkan dengan Madarasah Aliyah Swasta (MAN) yang ada di kabupaten Tanah Datar

Data dari kasi Mapenda penulis simpulkan bahwa nilai rata-rata UN tahun pelajaran 2011/2012 jurusan IPS untuk Madrasah Aliyah Negeri (MAN) sekabupaten Tanah Datar berada antara 5.63 - 6.69. Sedangkan nilai rata-rata UN untuk
Madrasah Aliyah Swasta (MAS) sekabupaten Tanah Datar berada antara 4.06 sampai 5.67.

Data di atas dapat memberikan gambaran bahwa kinerja guru pada Madrasah Aliyah Swasta (MAS) di kabupaten Tanah Datar dilihat dari prestasi belajar siswa relatif rendah di bandingkan dengan Madrasah Aliyah Negeri (MAN) yang ada di kabupaten Tanah Datar. Hasil belajar siswa bagus / tinggi maka dapat dikatakan bahwa guru berhasil atau berprestasi tinggi . Sebaliknya kalau prestasi siswanya rendah, maka hal itu merupakan pertanda hasil kerja guru rendah.

Di samping itu ada sebagian kepala Madarasah Aliyah Swasta (MAS) yang sering meninggalkan tugas karena kesibukan yang tidak ada kaitannya dengan kedinasannya (Wawancara dengan salah seorang guru pada MAS yang ada di kabupaten Tanah Datar (Makhdalena Mansur.S.Pd) pada tanggal 15 Juli 2012. Ini berarti kepala Madarasah Aliyah Swasta (MAS) yang ditunjuk tersebut belum mampu untuk menjadi suri tauladan bagi warga madrasah yang dipimpinnya.

Salah satu bukti belum mampunya sebagian kepala Madrasah Aliyah Swasta dalam memimpin madrasah yang dipimpinnya yang diduga juga menjadi penyebab turunnya mutu pendidikan adalah terlihat guru belum bertugas secara professional artinya guru belum dibekali dengan keahlian khusus untuk penunjang profesinya. Dalam kegiatan proses pembelajaran ada sejumlah tugas yang harus dimiliki dan dilaksanakan oleh seorang guru, mulai dari pembuatan rencana pelaksanaan 
pembelajaran (RPP) yang merupakan disain dari sebuah proses pembelajaran yang akan dilaksanakan, pelaksanaan proses pembelajaran maupun pelaksanaan kegiatan evaluasi dan pelaksanaan kegiatan remedial serta pengayaan.

Dari observassi awal yang penulis lakukan dengan mengadakan wawancara dengan salah seorang pengawas madrasah (Drs.Nuzwil) yang berada di lingkungan Kementerian Agama kabupaten Tanah Datar pada tanggal 3 Agustus 2012 diperoleh informasi bahwa sebagian guru pada Madrasah Aliyah Swasta (MAS) di kabupaten Tanah Datar masih sering datang terlambat, mengajar sekedar melepas kewajiban belaka, mengajar tanpa program dan tujuan yang jelas, tidak mempersiapkan media, keluar kelas cepat dari waktu yang ditentukan, kalau bertemu kepentingan pribadinya dan kepentingan madrasah atau dinas maka sering kepentingan madrasah yang ditinggalkan bahkan ada guru yang mengajar pada salah satu Madarasah Aliyah Swasta (MAS) yang ada di kabupaten Tanah Datar yang setiap hari kamis tidak masuk dinas hanya karena alasan yang tidak bisa diterima dari segi kedinasan.

Hal tersebut di atas menunjukkan tugas kepemimpinan atau pembinaan yang dilakukan oleh sebagian kepala Madarasah Aliyah Swasta (MAS) tersebut belum terlaksana dengan baik. Salah satu fungsi kepala madrasah tersebut adalah memberikan pembinaan dan ketauladanan kepada orang-orang yang dipimpinnya.
Juga yang termasuk tugas seorang kepala madrasah adalah membina terjalinnya kerja tim yang baik dimadrasah yang dipimpinnya.

Kepala sekolah sebagai pemimpin sekolah bukan hanya memiliki peran kuat dalam mengkoordinasikan melainkan juga menggerakkan dan menyerasikan semua sumber daya pendidikan yang tersedia di sekolah. Kepemimpinan kepala sekolah merupakan salah satu faktor yang dapat mendorong sekolah untuk mewujudkan visi, misi, tujuan dan sasaran sekolahnya. Kepala sekolah dikatakan berhasil apabila mereka memahami keberadaan sekolah sebagai organisasi yang kompleks dan unik, serta mampu melaksanakan perannya dalam memimpin sekolah.

Dari pendapat di atas menunjukkan bahwa kepala madrasah sebagai pemimpin suatu lembaga harus menyesuaikan perjalanan (kinerja) organisasi dengan tujuan yang hendak dicapai. Hal ini dilakukan supaya apa yang akan dicapai oleh lembaga pendidikan tidak saja menjadi rencana belaka tapi direalisasikan dalam dunia nyata.

Penelitian ini dilakukan di Madarasah Aliyah Swasta (MAS) se Kabupaten Tanah Datar. Penelitian akan dilakukan mulai dari bulan Desember 2012 sampai bulan Januari 2013. Populasi penelitian ini adalah 386 guru Madarasah Aliyah Swasta (MAS) sekabupaten Tanah Datar seperti yang dijelaskan di atas. Masa dinas dan tingkat pendidikan dipertimbangkan karena akan ikut berpengaruh terhadap kinerja guru pada Madarasah Aliyah Swasta (MAS) 
sekabupaten Tanah Datar tersebut. Untuk itu tingkat pendidikan akan dikelompokkan kedalam kelompok $\geq S 1$ dan di bawah $S 1$. Kemudian masa dinas dibedakan mengisi masa dinas 10 tahun ke atas, dan masa dinas kecil dari 10 tahun.

Sampel diambil dengan menggunakan teknik stratified proportional random sampling. Dengan teknik ini diharapkan dapat diperoleh sampel secara proporsional untuk setiap kelompok yang dipilih secara acak. Pengambilan sampel dilakukan melalui 4 tahapan, yaitu : (1) identifikasi antara strata dan pengelompokan populasi berdasrkan strata, (2) pencarian proporsi berdasarkan strata, (3)penentuan ukuran sampel, (4) penentuan subjek penelitian secara random sebanyak 15\% dari 386 guru.

Permasalahan yang diajukan dalam penelitian ini yaitu: apakah terdapat pengaruh yang signifikan kepemimpinan kepala madrasah terhadap kinerja guru MAS se-Kabupaten Tanah Datar.

\section{PEMBAHASAN}

Data variabel Kinerja Guru Madrasah Aliyah Swasta (MAS) se-kabupaten Tanah Datar diperoleh dari 33 butir pernyataan. Idealnya skor variabel Kinerja Guru Madrasah Aliyah Swasta (MAS) se-kabupaten Tanah Datar menyebar antara 131 (terendah) dan 235 (tertinggi). Selanjutnya diperoleh skor rata-rata (mean) sebesar 197.59, skor tengah (median) sebesar 203.00, skor yang banyak muncul (mode) 195 dan simpangan baku (standard deviation) 24,107. Untuk memperoleh gambaran yang jelas tentang distribusi skor variabel Kinerja Guru Madrasah Aliyah Swasta (MAS) se-kabupaten Tanah Datar dapat dilihat pada tabel berikut :

Selanjutnya tingkat pencapaian responden pada variabel Kinerja Guru Madarasah Aliyah Swasta (MAS) sekabupaten Tanah Datar diperoleh 82,37\%. Proses perhitungan dapat dilihat pada lampiran 4. Capaian ini termasuk kategori baik. Dari data ini dapat dikatakan bahwa Kinerja Guru Madrasah Aliyah Swastan (MAS) se-kabupaten Tanah Datar pada umumnya berada dalam kategori baik.

Data variabel Kinerja Guru Madrasah Aliyah Swasta (MAS) se-kabupaten Tanah Datar diperoleh dari 50 butir pernyataan. Idealnya skor variabel Kepemimpinan Kepala Madrasah menyebar antara 110 (terendah) dan 249 (tertinggi). Selanjutnya diperoleh skor rata-rata (mean) sebesar 194,58 skor tengah (median) sebesar 202.00, skor yang banyak muncul (mode) 202 dan simpangan baku (standard deviation) 34,698 .

Selanjutnya tingkat pencapaian responden pada variabel Kepemimpinan Kepala Madrasah 78 \%. Proses perhitungan dapat dilihat pada lampiran 4. Capaian ini termasuk kategori cukup. Dari data ini dapat dikatakan bahwa Kepemimpinan Kepala Madrasah Aliyah Swastan (MAS) se-kabupaten Tanah Datar pada umumnya berada dalam kategori cukup. 


\section{Temuan Penelitian}

Setelah diadakan analisis pada setiap indikator dari setiap variabel maka dapat penulis kemukakan rata-rata pada masingmasing variabel, tingkat pencapain responden dan kategori perolehan sebagai berikut :

a. Pada variabel Kinerja Guru taraf pencapaian responden (tcr) semua indikator rata-rata berkategori baik. Hal ini mengambarkan bahwa kinerja guru pada Madrasah Aliyah Swasta di kabupaten tanah datar sudah cukup baik.

b. Pada variabel Kepemimpinan Kepala Madrasah didapati taraf pencapain responden sebagai berikut :

1) Pada indikator kepala madrasah mengarahkan guru dalam melaksanakan tugasnya sebagai tenaga pendidik dan memberikan keteladanan kepada warga sekolah berkategori baik

2) Pada indikator memotivasi guru, memfasilitasi kegiatan sekolah, membimbing guru dan dalam melakukan kegiatan kepengawasan berkategori cukup.

c. Pada variabel Kerja Tim didapati taraf pencapain responden sebagai berikut :

1) Pada indikator keikhlasan, keterbukaan, keakraban, dan mementingkan kepentingan bersama berkategori baik.

2) Pada indikator saling menghargai berkategori cukup.

\section{Uji Hipotesis}

Hipotesis pada penelitian ini adalah "Kepemimpinan Kepala Madrasah Berpengaruh Secara Signifikan terhadap Kinerja Guru Madrasah Aliyah Swasta (MAS) se-kabupaten Tanah Datar". Untuk menguji hipotesis ini digunakan analisis korelasi dan regresi sederhana. Pengujian hipotesis ini dilakukan dengan menggunakan hipotesis sabagai berikut :

$H o=$ Tidak terdapat pengaruh yang signifikan antara Kepemimpinan Kepala Madrasah tehadap Kinerja Guru Madrasah Aliyah Swasta (MAS) se-kabupaten Tanah Datar.

$H 1=$ Terdapat pengaruh yang signifikan antara Kepemimpinan Kepala Madrasah tehadap Kinerja Guru Madrasah Aliyah Swasta (MAS) sekabupaten Tanah Datar

Dasar pengambilan keputusan adalah bahwa diterima Ho jika nilai signifikasi > Alpha 0,05 atau H1 jika siknifikasi < Alpha 0,05 .

Hasil perhitungan korelasi Kepemimpinan Kepala Madrasah Kinerja Guru Madrasah Aliyah Swasta (MAS) se-kabupaten Tanah Datar dapat dilihat pada Lampiran 6 dan dirangkum pada Tabel XVII di bawah ini :

Tabel 2

XVIII Rangkuman Hasil Analisis Korelasi X1 - Y

\begin{tabular}{|l|c|l|l|c|}
\hline Korelasi & N & Koefisien Korelasi $(\mathbf{r})$ & Koefisien Determinasi $\left(\mathbf{r}^{2}\right)$ & Sig. \\
\hline Ry1 & 59 & 0.491 & 0.241 & $0.000^{2}$ \\
\hline
\end{tabular}

Dari hasil analisis diperoleh angka koefisien variabel Kepemimpinan Kepala 
Madrasah dengan variabel Kinerja Guru Madrasah Aliyah Swasta (MAS) sekabupaten Tanah Datar (ry1) sebesar 0.491. Angka korelasi ini menunjukkan bahwa hubungan Kepemimpinan Kepala Madrasah dengan Kinerja Guru Madrasah Aliyah Swasta (MAS) se-kabupaten Tanah Datar berkorelasi positif. Selanjutnya tabel memperlihatkan angka koefisien determinasi sebesar 0.241 dengan signifikasi sebesar 0.000 . Sesuai dengan pengambilan keputusan di atas maka Ho ditolak dan $\mathrm{H} 1$ diterima. Ini berarti terdapat pengaruh yang signifikan antara Kepemimpinan Kepala Madrasah terhadap Kinerja Guru Madrasah Aliyah Swasta (MAS) se-kabupaten Tanah Datar dengan kontribusi sebesar 24,1\%.

Berdasarkan pada hasil analisis data dan tingkat pencapaian respon guru Madrasah Aliyah (MAS) di Kabupaten Tanah Datar terhadap variabel-variabel yang diukur, maka dapat dijelaskan bahwa tingkat pencapaian respon guru terhadap variabel kinerja guru termasuk kategori baik (82\% dari skor ideal), untuk variabel kepemimpinan kepala madrasasah termasuk kategori cukup (78\%), dan perlu untuk ditingkatkan. Temuan penelitian ini berbeda dengan hasil pengamatan awal yang peneliti lakukan. Pengamatan awal menemukan bahwa kinerja guru Madarsah Aliyah (MAS) di Kabupaten Tanah Datar terlihat masih rendah. Perbedaan temuan penelitian dengan temuan pengamatan awal terjadi karena hasil pengukuran yang dilakukan berdasarkan pengamatan saja atau tanpa instrumen yang valid dan reliabel tidak cukup kuat untuk dijadikan dasar dalam melakukan generalisasi, sehingga perlu dilakukan penelitian yang sistematis sesuai dengan prosedur, untuk mendapatkan pembuktian dan kebenaran secara empiris.

Hasil analisis data dan pengujian hipotesis menunjukkan bahwa hipotesis yang diuji dalam penelitian ini dapat diterima. Hasil analisis data menunjukkan bahwa kepemimpinan kepala madrasah memiliki pengaruh atau peranan yang berarti untuk meningkatkan kinerja guru Madarasah Aliyah Swasta (MAS) se-Kabupaten Tanah datar.

Dari hasil analisis yang telah dikemukakan pada bagian sebelumnya dapat dijelaskan bahwa variabel bebas berkorelasi secara signifikan dan positif dengan varabel terikat. Hasil analisis data dan pengujian hipotesis menunjukkan bahwa hipotesis yang diuji dalam penelitian ini diterima secara empiris. Dengan demikian, dapat diyakini bahwa variabel Kepemimpinan Kepala Madrasah berkontribusi terhadap Kinerja Guru pada Madrasah Aliyah Swasta (MAS) se-kabupaten Tanah Datar

Temuan penelitian ini, didukung oleh pendapat Siagian bahwa ada beberapa faktor yang dapat mempengaruhi kinerja antara lain : (1) Intelegensi, (2) Sikap, (3) Kemampuan professional guru, (4) Ketrampilan menajemen, (5) Suasana atau iklim kerja sama (kerja tim), (6) Keamanan dan perlindungan kerja, (7) Perencanaan, 
(8) Pengawasan, (9) Motivasi internal, (10) kepemimpinan kepala sekolah.

Kepemimpinan yang merupakan prilaku yang konsistem dari seorang pemimpin juga diduga ikut mempengaruhi kinerja sesungguhnya. Hal ini dimungkinkan demikian karena seorang pemimpin yang efektif akan dapat mengugah atau mempengaruhi orang lain untuk melakukan sesuatu. Seorang pemimpin adalah orang yang paling bertanggung jawab dalam perkembangan dan peningkatan mutu dari sebuah lembaga yang dipimpinnya, baik di lembaga yang tidak resmi ataupun di lembaga-lembaga resmi seperti lembaga pendidikan dan sebagainya.

Jika kepemimpinan di sebuah madrasah tersebut dapat berjalan dengan baik maka kinerja guru yang dipimpinnya tersebut akan baik atau meningkat sesuai dengan tujuan yang telah ditetapkan sebelumnya. Jika kinerja guru sudah baik maka dengan sendirinya mutu pendidikan dimadrasah tersebut akan semakin baik.

Sebagai pemimpin pendidikan kepala madrasah mempunyai tanggungjawab yang cukup berat untuk meningkatkan kinerja guru pada madrasah yang dipimpinnya, oleh karena itu harus mempunyai persiapan dan kemampuan yang memadai. Ia juga harus mempunyai inisiatif dan keberanian untuk menunjukkan dirinya sebagai pemimpin yang membina dan membantu guru mengembangkan diri secara terus menerus. Dia harus mampu mendorong, menggerakkan, dan mempengaruhi orang lain untuk mau bekerjasama dengannya. Sebagai pemimpin, kepala madrasah bertanggungjawab dalam mempengaruhi, membimbing, mengarahkan dan mengkoordinir semua yang ada dilingkungannya.

Kepemimpinan kepala madrasah merupakan faktor eksternal yang mempengaruhi kinerja guru yang bersumber dari luar guru. Pendekatan kepala madrasah menerapkan kepemimpinannya dalam membimbing dan memotivasi guru akan berdampak tinggi atau rendahnya kinerja guru. Keberhasilan atau kegagalan suatu madrasah dalam menampilkan kinerjanya secara memuaskan banyak tergantung pada kualitas kepemimpinan kepala madrasah. Dengan demikian kepemimpinan kepala madrasah penting karena dengan adanya ketepatan kepala madrasah dalam menerapkan kepemimpinan, maka akan memudahkan mengajak guru untuk bekerja sama dalam bekerja sesuai dengan yang diharapkan madarasah untuk memajukan dan meningkatkan mutu pendidikan. Kepemimpinan kepala madrasah akan terlihat dalam proses dalam mengarahkan guru, memberikan dorongan kepada guru, memfasilitasi kegiatan sekolah, membimbing guru, dan memberikan ketauladanan.

Berdasarkan hasil analisis deskriptif terlihat bahwa kepemimpinan kepala madrasah termasuk kategori cukup dengan tingkat pencapaian respon $78 \%$ dari 
skor ideal. Ternyata dari lima indikator kepemimpinan kepala madrasah yang dikaji, ditemukan bahwa dua indikator berada pada kategori baik yaitu indikator mengarahkan guru, dan memberikan ketauladanan, sedangkan empat indikator yaitu memberikan dorongan kepada guru, memfasilitasi kegiatan sekolah, membimbing guru, dan melakukan kegiatan kepengawasan berada dalam kategori cukup, maka pada indikator-indikator ini masih dapat ditingkatkan atau diperbaiki ke arah yang lebih baik lagi

Hasil analisis ini menunjukkan bahwa kepemimpinan kepala madrasah pada Madrasah Aliysah Swasta di kabupaten Tanah Datar perlu untuk ditingkatkan ke arah yang lebih baik. Peningkatan kepemimpinan kepala madrasah ini bertujuan agar dalam pelaksanaan tugasnya kepala madrasah memiliki rasa tanggung jawab yang tinggi dan kesungguhan terhadap pekerjaannya.

Soemanto dan Soetopo (1988) mengemukakan bahwa cara kerja kepala madrasah dan cara ia memandang peranannya dipengaruhi oleh kepribadiaanya, persiapan dan pengalaman profesionalnya, serta ketetapan yang dibuat oleh kepala madrasah mengenai madrasah di bidang pembelajaran.

Pada dasarnya seorang pemimpin harus memiliki kepribadian sebagai seorang pemimpin, kebijaksanaan, kebajikan dan keadilan, serta ketegasan dalam bertindak. Jelaslah bahwa seorang pemimpin harus memahami setiap kepribadian yang secara pasti berbeda dengan kepribadiaanya sendiri. Pemimpin sebagai suatu kepribadian memiliki motivasi yang tidak sama dengan motivasi anggota kelompoknya, baik dalam mewujudkan kehendak untuk bergabung dan bersatu dalam satu kelompok, maupun dalam melaksanakan kegiatan yang menjadi tugas dan tanggung jawab masing-masing. Dalam kenyataanya seorang pemimpin merupakan pribadi sentral yang sangat besar pengaruhnya terhadap anggota organisasi yang terlihat dalam sikap dan perilakunya pada waktu melaksanakan peranannya.

Dalam kaitannya dalam pengamalan pribadi, Madhi dalam Mujamil Qomar (2003) mengajukan resep keteladanan melalui seruan berikut : "Wahai pemimpin, supaya anda dapat menjadi teladan dan contoh serta dapat memetik hasilnya, jadilah orang disiplin, proaktif, rendah hati, relistis, dan penyayang." Agaknya seruan ini merupakan penjabaran dari ungkapan singkat yang menjadi pegangan sahabat Nabi dan ulama berikutnya, yaitu ibda' binafsik (mulailah dengan dirimu). Jika sudah dimulai atau diberi contoh keteladanan, orang lain akan mengikutinya. Cara ini merupakan sikap konsisten antara apa yang diinginkan dari para bahawan dengan apa yang dipraktekkan sebagai keteladanan. Keinginan dan keteladanan harus sejalan seiring, bahkan keteladanan harus didahulukan, baru keinginan itu akan tercapai. 


\section{PENUTUP}

Berdasarkan data dan hasil analisis yang telah dipaparkan dapat ditaik kesimpulan sebagai berikut : Kepemimpinan kepala madrasah berpengaruh secara signifikan terhadap kinerja guru pada Madrasah Aliyah Swasta (MAS) se-kabupaten Tanah Datar sebesar $24,1 \%$. Ini berarti $24,1 \%$ varian yang terjadi pada kinerja guru pada Madrasah Aliyah Swasta (MAS) se-kabupaten Tanah Datar merupakan kontribusi dari faktor kepemimpinan kepala madrasah. Kinerja guru dapat ditingkatkan bila kepemimpinan kepala madrasah diperbaiki.

Berdasarkan temuan penelitian ini, maka peneliti mengemukakan beberapa saran sebagai rekomendasi kepada berbagai pihak sebagai berikut :

1. Kepala-kepala Madrasah Aliyah Swasta (MAS) di kabupaten Tanah datar :

a. Diharapkan dapat melaksanakan fungsinya sebagai kepala madrasah dengan baik.

b. Diharapkan sebagai pimpinan kepala madrasah agar dapat memberdayakan seluruh potensi yang ada, meningkatkan reputasi sekolah masa depan, menumbuhkembangkan potensi kepemimpinan tanpa mengorbankan pihak lain. Dalam hal ini, kepemimpinan kepala madrasah hendaknya mampu mempengaruhi dirinya dan orang lain sehingga secara sukarela bekerja dan ikhlas mencapai tujuan bersama.
2. Para guru Madarasah Aliyah Swasta (MAS) se-Kabupaten Tanah Datar diharapkan untuk dapat meningkatkan kinerja sebagai agen pembelajaran. Mendukung kepemimpinan kepala madrasah dan menciptakan kerja tim yang baik dengan sesama warga madrasah.

3. Pengawas sebagai tenaga supervisi pendidikan hendaknya berperan membantu dan merubah (to help dan to change) kepemimpinan kepala madrasah dan kerja tim sesama warga madrasah sebagai upaya untuk meningkatkan kinerja guru. Dengan tugas ini, pengawas hendaklah cakap, berwibawa, dan mempunyai kompetensi yang lebih baik dari guru dan kepala madrasah.

\section{KEPUSTAKAAN ACUAN}

Abdul Halim Hanafi, Metode Penelitian Kependidikan, Batusangkar: STAIN Batusangkar Press,2011

Hendityat Soetopo dan Wasty Soemanto, Kepemimpinan dan Supervisi Pendidikan,

M. Ngalim Purwanto, Administrasi dan Supervisi Pendidikan, Bandung: PT. Remaja Rosdakarya, 2004

Mujamil Qomar, Manajemen Pendidikan Islam, Malang : Erlangga, 2003

Panji Anoraga, Psikologi Kepemimpinan, Jakarta: PT Rineka Cipta,2003

Sondang P.Siagin, Menajemen Sumber Daya Manusia, Jakarta : Bumi Aksara, 2002 